\title{
Зоран Арсовић*
}

\section{ФИЛОЗОФИЈА И СОФИСТИЧКИ ДУХ ВРЕМЕНА}

\section{Philosophy and the Sophistic spirit of the time}

Abstract The paper deals with the philosophical analysis of the spirit of the time and the thematization of the so-called crisis of the polis. The main intention is to show its importance not only for the purpose of finding out about the fifth century, but for the purpose of understanding our own time as well.

Key words Sophistic spirit of the time, nomos, physis, reason, mind, philosophy.

Сажетак: Рад се бави филозофском анализом духа времена и тематизаиијом тзв. кризе полиса. Основна намјера је показати њихову значајност не само за упознавање ситуаиије V вијека п. н.е., већ и за разумијевање властите.

Кључне ријечи: софистички дух времена, потоs, physis, разум, ум, филозофија.

$\mathrm{V}$ вијек п. н. е, вријеме је то када у потпуности свиће онај појавом полиса и пробојем логоса најављивани дан. Грчки дух одавно га слути, о њему пјева и приче тка. Платон их преузима, уграђује у дијалоге, настављајући проносити стару вијест о „дану божјег преокрета“ (то је главни разлог зашто себи дајемо за право да платоновском четкицом осликамо ово доба). И сам ће рећи: све

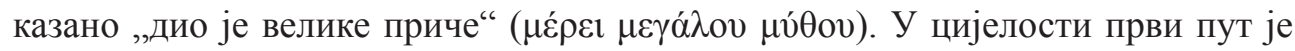
износи у Државнику (у нешто измијењеном облику понавља у Законима), прича је Странац и назива „шалом“, дјетињаријом ( $\left.\pi \alpha 1 \delta \iota^{\prime} v\right)$. Али одмах упозорава саговорника да пажљиво слуша „баш као што дјеца то чине“ (Државник, 268д), јер говори се о „озбиљним стварима“ и озбиљно се говори. А кад је тако, дјечја ангажованост при слушању је нужна. И кад би њу поново успијели пробудити, па се око старе приче сабрати, и „позив“који Платон одашиље могао би постати најсвојственији.

Прича говори о двије епохе - Хроново доба, кад бог управља свемиром (,кад је свега самог од себе било у изобиљу“, Закони, 713ц) и Зевсово доба или „оно сада“ ( друге епохе јесте да бог који је „кормилар свемира“ (

\footnotetext{
* Ванредни професор филозофске групе предмета на Филозофском факултету у Бањој Луци
} 
оставља свијет и окреће се, а с њим и „сви нижи демони и хероји...; бог оставља држало кормила и одступа у своју стражарницу, а свијет даље окрећу судбина и

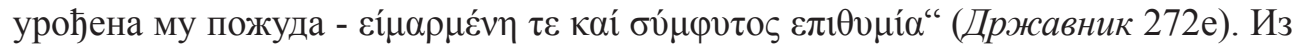
топлине, близине божанског, свијет се окреће у хладноћу зиме. У таквом свијету, остављеном да управља и влада собом ,jача постепено оно тјелолико“ ( $\sigma \omega \mu \alpha \tau о \varepsilon 1 \delta \eta ́ s, 273 \sigma)^{1}$, мијеша се у божанско, те квари и полис и човјека. У ствари, кварење слиједи образац кретања повијести у епохи самосталног свијета. Као и свијет, и човјек је напуштен - лишен божанске бриге и заштите, живећи у животу у ком се ништа од себе не нуди већ се сустеже, скрива и ускраћује (многи аутори сматрају да је овај мит уграђен у темељ Платонове филозофије повијести, па и метафизике слободе). Оставши сам, човјек се ослоња на себе и на своју природу, али бог зна: „никаква човекова природа није способна да сама управља људским стварима, а да је не испуни неправда и hybris“ (Закони, 713e). „Природно“ нема мира и здравога живота. „Природно“ полис је у рату и претпоставља сукоб.

Само кад бог држи кормило сукоба нема. Влада потпуни и савршен мир - eirene. „Држава је здрава“ (бог држи свијет, а божански пастири људе изводе на пашњак, Државник, 271 д). Термин којим се означава заједница као „божанско стадо“ јесте oikesis (Закони, 713б) - органски саживот. Док је „здравља“ полиса нема. Он означава тренутак кад се „прешло преко“ здравља. А кад се једном „пређе преко“ повратка нема, јер ,људско стање“" не репродукује се једноставно, већ се шири, настаје, производи. Ово произвођење производи и стална удаљавања од искона, што за собом вуче непрестано умножавање hybrisa.

И стигло се до кључног платоновског парадокса. Он је (проткивајући све ,Политичке“ дијалоге) окосница грандиозне драме, праве historia проблематичности човјековог града која се у дијалозима поставља. Да би се могло говорити о полису, ући у политичку аргументацију, хипотеза о здравој држави мора се напустити. О полису не можемо говорити да je oikos a да га не уништимо - јер би игнорисали онај саму њему примјерен импулс раста и воље за моћи. Град није „стадо“, јер кад би то био не би био град. Краљ-филозоф, чак и кад би га усуд и додијелио, никад неће бити бог. И најпросвјећенијем владару требаће polemos, он сам мораће да буде polemikos (онај који познаје технике рата), мада полемос „ни на који начин није оно најбоље“ (Закони, 628ц). Без polemosa полис се не може уобличити, а, с друге стране, он га засигурно води у смрт. Ужасна је стварност људских ствари. Излаза изгледа нема.

За многе ауторе то је и главни разлог зашто Платон бјежи у дистанцираност од сваког стварног уређења из које онда гради утопију која, апстрактно из неког принципа, изводи устројство јединственог полиса. Зато Платон и нема очи за конкретну реалност политичког. А имају ли се у овој оптужби очи за Платона? Или се безрезервно прихвата Аристотелов поглед а на Платона се и не осврће. Јер у противном видјели бисмо да нам је управо та дистанцираност,

1 У Критији се говори „божанском удјелу ( мјеша са смртним“ (Критија, 121а). 
комично трагична дистанцираност у односу на сваку стварну државу, омогућила да уочимо апорије сваке државе. Шта је друго отворило и држало отвореном сурову истину стварности? Отуд и свака намјера да се Платонова аргументација (у овим стварима) отрјежњава начелно промашује, јер не може се тријезнити оно што је савршено отрјежњено. Аргументација се може одбацити или прихватити, али критиковати је што занемарује многострокуст устројстава и многострукост полиса, као што то чини Аристотел, значи остати и глув и слијеп за платоновску политичку драму (драму политичког) ${ }^{2}$.

На моменте Платон изгледа као потпуни „фаталиста“ јер упорно истрајава на томе да само бог дарује заједничке врлине, чак и филозофа-краља рађа (даје) божански усуд. Али тиме он ниједног трена не жели рећи како старе вриједности у полису више нису могуће већ само то да се о њима може мислити, односно, да се мора мислити - јер како би уопште било замисливо само оно многоструко полиса (као многоструко) ако се не би имала никаква идеја о јединству $?^{3}$

Из платоновског фатализма дакле не исходи препуштеност и не-дјелање, већ једна нарочита активност. Тачно је, здравља више нема, са људима који живе у миру и здрављу (en eirénai metá hygieias) и тај начин живљења потомцима несметано преносе, мора се поздравити (опростити), али управо тај недостатак „гони“ да се љекари и љекарије траже више него икад (Држава, 373д). Оно што је пријеко потребно јесте увид.

И ето простора, епохалне сцене, на којој је филозофији суђено да се појави. Само је традиција „немарног читања“ Платона могла смотрен Гајзеров став учинити чувеним: филозофија је могућа само у „другој епохи“ свијета, у епохи одлазеће хармоније бога, али ипак специфично: филозофија је оно једино преостало што је још увијек некако везано и за прву епоху (отуд је међуигра епоха кључна за разумијевање почетног карактера филозофске дјелатности) ${ }^{4}$.

2 Видјети оп: М. Качари; Геофилозофија Европе, Београд, 2010, стр. 26-32. “Безглавој брзини духа што лежи у темељу нашег модерног разумијевања политике неметнуто је захваљујући опасности глобалног уништења још толико времена за промишљање да је можда у међувремену нарасла и спремност да тог мислиоца (Платона) који се с једне стране усудио мислити оно радикално друго, а с друге, знао избјећи нововјековно бркање револуције и озбиљења Добра, управо због тога призна еминентно политичким мислиоцем“" (T. A. Szlezák; Psyche-PolisKosmos. Bemerkungen zur Einheit des platonischen Denkens, u: Polis und Kosmos. Naturphilosophie und politische Philosophie bei Platon, Darmstadt, hrsg. E. Rudolph, 1996, str. 28-29). Платонов нацрт стога није утопија него увијек нешто више од ње - оно уистину тешко али не и немогуће - наиме, ступање идеје Добра у политички свијет (које је везано за божаснки усуд). Али да би се платоновски путеви јединства који већ с Арситотелом здравом разуму изгледају немогући, а нама тако натегнути, потребна је, каже Слезак „плтаоносвка теорија почела.., потребно је отворити очи за далекосежност Платонових ријечи које долазе из Аристотеловог свједочења: за Једно са̂мо веле да је Добро са̂мо (Метафизика, 1019б)".

3 М. Качари, нав. дјело, стр. 34.

4 K. Geiser; Platons Ungeschriebene Lehre: Studien zur systematischen und geschlichtlichen Begründung der Wissenschaften in der Paltonischen Schule, Stuttgart, 1963, str. 288. „Намјесто једног једноставног природно датог поретка живота све више ступа нужност одлуке између арете и 
Пошто више нисмо „синови богова“, каже Платон, те „излажемо људима а не боговима“" ваља ући у стање које затичемо, тј. сручити се у истину своје епохе. Платонови Закони „величанствен“ су и „дуго припремани улаз“ (који се одвија на позадини велике приче „о дану божјег окрета“) у сурову истину „да државе у којима власт нема бог него смртник не могу избјећи зла и муке“ (Закони, 713е).

Продирући оно „сада“, описујући га, Платон као да дотиче срж сваког „сада“ - јер свако „сада“ непромијењено окреће судбина и урођена јој пожуда. То су унутрашњи, самостални, а данас бисмо рекли, и „,ауторегулативни покретачи и принципи свијета“"5. На тај начин баш у времену постоји „оно нешто“ што се не мијења и сваки пут је „исто“- његове стихије које човјека узимају и разносе. Пошто до данас оне „звижде увијек исту перспективу“ и „носе увијек исту мудрост“, платоновске анализе су драгоцјене не само за упознавање ситуације V вијека, већ и за разумијевање властите. А с друге стране, њима је са ненадмашивим осјећајем за реалност Платон уписао задаће филозофији и утиснуо јој такав карактер кога ће сваки озбиљнији модерни мислилац означити непролазним, и више или мање свјесно, на њега се увијек позивати. Иза сваке модерне приче о поновном изналажењу оног људског поврх субјективитета (или у дубини тог субјективитета), о силаску у „сиромаштво егзистенције“ (Хајдегер), о са-припадности филозофије и егзистенције, у ствари стоји Платон. На момент у пуној истини бљесну Вајтхедове ријечи: сва филозофија само је неколико фуснота уз Платона ${ }^{6}$. Када Олимпиодор прича о пчелама са Химета које у уста малом Платону стављају медено саће као предзнак будућег дара „најслакторјечивије словесности“ (Лосев), као да се оквири легенде размичу за истинитост нарочите врсте: Платон је име за оног ко умије свако вријеме учинити широким (платоо̃ - чинити широким).

Говор о „дану божјег окрета“ није филозофски изум, већ, како то потврђује и Платон, вијест која долази из старине. Филозофија профилише и артикулише древно искуство грчког човјека присутно још код Хомера (његови јунаци себе виде увијек слабијим у односу на претке), а кога у потпуности

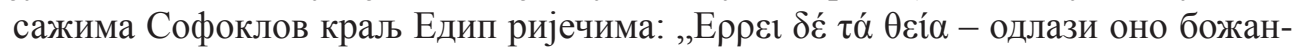
ско“. Грчка поезија увелико пјева узносећи властити проблем и итекако увиђа

какиа. Одговарајући темељној законитости историјског развитка по ком се дизање умног сазнања и нарастујуће растројење праизворних поредака збивају истовремено, мора филозофски увид да буде историјски закаснио и да се догађа временски уједно са стањем далеко узнапредованог растројења спољашњих поредака живота““ (стр. 71).

5 О. Жунец; Морепловство и полис у Платоновој Политеји, у: Филозофирање и море, Заргреб, 2008, стр. 246;.

6 „Не мислим на систематску схему мисли коју су учењаци непоуздано извукли из његових списа. Алудирам на обиље општих идеја које су по њима расуте. Његови лични дарови, широке погодности да се он иксуствује кроз један велики период цивилизације, његово насљеђе у интелектуалној традицији које још није ускраћено претјераном систематизацијом, учиниле су његове списе неисцрпним рудником сугестије“ (А. N. Whitehead; Adventures of Ideas, Cambridge Univesity Press, 1961, str. 229-230). 
опасност да се „у времену узмака богова“ претвори у „бљештаву и шарену лажу“ која је „украшеном опсјеном“ допадљива само „слијепом срцу гомиле“ (Пиндар, Нем. 7, 24).

Отуд ни „крај архајског доба“" не може бити пука појава већ знак божанског обрата - судбинско дешавање. И само кроз ове „наочаре” филозофија посматра збивања свог времена (и онда кроз њих треба и њу посматрати). Њу не интересују разлози објективног слиједа догађаја и њихови узроци, већ са̄ма могућност догађања. Она је „битно мишљење“. Као такво налаже да се раскрсти са наивним (и посве суманутим) представама модерности по којима је филозофија безбожничка „сила“ која „богове тјера“ из полиса. Супротно, она је једина која узмак божанскога мисли, а самим тим и једина која остаје на његовом трагу те мишљењем дохвата преосталу светост да она сасвим не ишчили. У промијењеним околностима она чини исто што и мит. Има ли филозофија уопште других задаћа па чак и онда када (као данас) у потпуности гасне тај траг од светога? Није ли „божанско“ одсутност од које које човјек живи? И је ли једно „одважније покоравање“ напросто судбина филозофије?

Платонови описи стања након ,дана божјег окрета“ актуелни су јер у танчине показују шта се збива са човјеком и његовом заједницом када се везе са цјелином стварности покидају. А, то је, признаће се, нешто што се судбински тиче и нас и Грка, на једнак начин?

Јединство митолошке слике свијета се распада, а са јединством космичког поретка распада се и отиче јединство моралног поретка у полису. Напросто, док је некад мит био у стању одражавати механизме стварног поретка друштва тако да су морални и вриједносни облици процјена претпостављали затворен облик функционалне организације сада то више није случај. Хармонија природних и друштвених закона је нарушена. Тим нескладом отвара се простор за гледишта по којима обичаји и закони, напросто све норме, а понајприје њихово важење, нису дио непромјењивог реда ствари већ ствар договора, конвенције. А кад се оваква гледишта устале тад постаје могуће износити и прихватати најразличитије ставове. У принципу сви ти ставови без обзира на разноликост баратају једном идејом - идејом номоса у значењу закона, која изниче из антитезе nomos - physis. Могућност да се термин „nomos” користи у овом уском смислу свједочи о стварању фундаментално другачијих (нових) основа̂ мишљења и поступања. Кад се мијења лице града мијења се и лице номоса (ова два термина прате се у стопу, готово ритуално) ${ }^{7}$. Из угла полисног (политичког) живота ново мишљење могло би се означити као „кратистичко” - јер сматра да су државна уређења постала функција владавине (kratos), тј. оних у чијим рукама је моћ и умијеће владања.

\footnotetext{
7 Односи између поретка и поријекла, између Орднунг и Ортунг, између поретка и мјеста, затим модерна Држава као ликвидатор античког номоса и средњевјековног республица ихристиана узимајући све то у обзир можда номос треба читати као причу о трагедији Европе, „постељи Хада“".
} 
Кратистичко мишљење настаје распадом старе “номистичке” парадигме мишљења којим влада древно значење термина номос. Првобитно номос значи како „важеће прописе“, „начин понашања“" и „начин живљења“ тако и у ширем смислу „животни“ или (веома уопштено схваћен) „правни поредак ${ }^{8}$. Хесиод, кога литература препознаје као првог корисника ријечи номос, изгледа да је познаје у оба значења, а можда и у широком семантичком распону од „појединачног правила до општег поретка“. Нит водиља свих ових значења јесте и остаје „нешто што важи“, дакле „нешто важеће“. Важење је увијек прописано и уписано оним што јесте - а за Грке јесу свијет богова и свијет physisa. Дакле, nomos произилази из свијета објективних чињеница, из стварних прилика - па је и разлика physisa и nomosa нејасна или сасвим непостојећа. Nomos je напросто све: право у најопштијем значењу, морал, обичај, традиција у једном. Такав nomos je божански. По њему све се одобрава и све извршава. Богови, једини способни за krainein, брину се и за људски поредак ${ }^{9}$. Пиндар пјева о „Закону који је владар свих ствари како смртних тако и бесмртних“; Хераклит говори о божанском номосу који ,може онолико колико хоће и за све је довољан и све надмашује“ (114, Д/К), из којег се хране сви људски номои. Град се придржава свог nomosa због заповједне и свеобухватне моћи божанског поретка. „Многи номои човјека не би могли сами по себи гарантовати поредак, ако не би водили порекло од божанског Nomosa. Њихов правни корен је онај који их повезује са космичком Dike. Ако је тако онда поштовање закона града треба да значи да су богови nomizein theous. Нема nomosa ако не постоји тај nomizein. Само убеђење да су богови ту може уверити да закони имају непромењиво корен““10.

Како и кад долази до „уписивања“ разлике људског и божанског nomosa? Гдје се тај упис најјасније оцртава и са ког мјеста је уопште читљив?

Биће да је то „поље политичког“ - како то обилато показује К. Мајер, кога на кратко овдје слиједимо ${ }^{11}$. Већ првобитна употреба термина nomos до-

\footnotetext{
8 Vidjeti: C. Schmitt; Der Nomos der Erde im Völkerrecht des Jus Publicum Europaeum, Köln, 1950, str. 37. Именица vó његовог првог појављивања у Илијади, глагол има два различита прелазна значења "раздијелити" (такође “подијелити”, “додијелити”) и “па̄сти” (дакле, “дати стоки на испашу”). Вијдети: F. Heinimann: Nomos und Physis. Herkunft und Bedeutung einer Antithese im griechischen Denken des 5 Jahrhunderts, Basel 1945; H. Gomperz; Sophistik und Rhetorik, Stuttgart, 1965.

9 “Krainein каже се о божанству које одобрава, и подражавањем божанског ауторитета, о краљу који даје извршну снагу неком пројкету или предлогу а да га сам не изводи. Дакле, kraino ce појављује као специфичан израз за ауторитативан чин, најприје божански, затим краљевски, а зависно од контекста способан и за друге примене - који допушта да се нека реч оствари у дело“. Однос kraínein према kára (глава), према Бенвенисту, омогућава изворније сагледавање значења израза: то је дозвола која се очитује покретом главе. Када Софокле користи kraínein „да би означио власт над неком земљом ... људска се власт одређује гестом који означава божански пристанак“. Божанска дозвола, климање бога главом, оно је што неку ријеч претвара у стварност. Због тога, „краљевска власт означена глаголом krainein потиче од геста којим бог дарује постојање нечему што би иначе било само реч“" (Е. Бенвенист; Речник индоевропских установа, Нови Сад, 2002, стр. 274-276).

10 М. Качари; Геофилозофија Европе, стр. 90.

11 Видјети К. Мајер; Настанак политичког код Грка, Београд, 2010, стр. 265-312.
} 
звољава, сматра он, одређена разликовања између битка и требања. Управо то разликовање које се временом све више продубљује уцртава разлику људског и божанског nomosa. Најприје, из појма nomosa настају други појмови попут eunomija, anomija - њихово је да опишу разна стања у којима се nomos добро или рђаво користи. Око 500 године п.н.е, први пут се спомиње nomos полиca (nomos poleos) и поставља паралелно са ksinon panton - то јесте „са општим, односно, са оним што је „ствар народа“ (као супротност од оног што је ствар тиранина ствар народа првобитно има означити оно што је по правди, богом дано). Nomos полиса није једнообразан чиме се већ најављује нешто ново: с једне стране, оно важеће се у различитим градовима различито очитује кроз посебан развој тих градова, нарочито кроз разноврсност закона - thesmoí. Свијест о томе се појачава и чињеницом да се људи све више почињу занимати за nomose других народа.

А управо то занимање (из ког произилази упоређивање) чини да се правни поредак исономних градова „оштрије“ проматра, што за собом повлачи и својеврсну промјену појма nomos (jep увид у разноликост важења уздрмава једно и непромјењиво важење). На тај начин се у V вијеку искристалисао потпуно нов смисао nomosa: он постаје „појам закона“. Али, како напомиње Majep, није се ово могло одиграти (како се обично учи),,једним вољним актом атинског грађанства у Клистеново доба“, јер би то значило да је у Атини тог доба „владала нововјековна свијест“ - што свакако није и не може бити случај. Ново значење nomosa израста као резултат једног дугог и постепеног процеca, и устаљује се вјероватно средином V вијека. По Мајеровој реконструкцији пут (која се прије свага тиче области политичког) изгледа овако: у Атини се у законским написима наилази на нарочита мјеста гдје се истовјетан закон, с једне стране, у формалном смислу означава као одлука законодавног тијела, а с друге, по свом садржају као nomos или nomion. Ово се може разјаснити само ако се претпостави да је nomos овдје употријебљен у значењу права које важи независно од свог извора, у смислу „прописа“ или „наредбе“, Кад се касније каже да nomos налаже шта треба чинити и шта је нужно да се дозволи, онда се то може примијенити како на „морал“ и „обичај“, тако и на „закон“. Очигледно није направљена разлика између писаних и неписаних правила понашања. Оно што би народ одлучио оваплоћено је у цјелокупности nomosa. Како nomos cве више постаје закон тако се и оно „важеће“ премјешта искључиво у оно написано, „од народа одлучено“. У том се иде толико да се остали обичаји писаним законима наглашено супротстављају као ágraphoi nómoi (неписани закони позната је чињеница да је постојала иницијатива да се законима појединих градова супротстави ta koina ton hellenon nomima). Иако се nomos поистовјећује са „законом“, његово шире значење се задржава јер се на тај начин појачава обавезујућа снага тих закона. Након што су ствари које је nomos одређивао постепено постајале предметом законодавства ова ријеч је са својим суштинским значењским опсегом прешла из материјалне у формалну област, што је довело до тога да су у демократијама писани закони постали гаранција правне сигур- 
ности и слободе. Услов за то јесте да се сфера оног што се може нормирати уреди законима. На тај начин јавила се могућност самовољног одлучивања и то вјероватно није био само повод за институционалне противмјере, већ истовремено и за истицање супротности између nómoi и psêphismata. С друге стране, услијед толике расположивости nomosa настао је проблем да се изгради један нерасположив противпојам. Због свега тога проблеми са појмовима nomos и physis су се распламсали.

А једном распламсали они више не избивају из подручја грчког живота. Напросто, нема више питања у кога не би била „уграђена“ антитеза physiscnomos $^{12}$. Расправа о религији покреће се у питању јесу ли богови по physisu (најбоље је превести у реалности) или по nomosu, односно, да ли и њих ствара неки законодавац да би спријечио човјека да крши закон кад није под присмотром? По истом моделу расправља се о политичкој организацији (држави), о владавини. Напросто, „ушло се у један свијет у којем и слатко и горко и вруће и хладно, али и правда и неправда, исправно и неисправно, постоје само у вјеровању или конвенцији“'13. Закони су сасвим људски. Али власт ауто-номних људи, исувише људска власт, мора водити у пропаст. Ово ће филозофија не само заступати већ настојати свуд унаоколо и показивати.

Једноставно, отварање грчког полиса, ширење простора људских ствари, приступ широког круга људи духовном животу, дакле, све оно што модерни демократски укус маркира као конститутивни елемент грчке културе, за филозофију је истовремено знак полисног опадања. Она је израз мисаоне реакције на такву врсту отварања (и стога представља градитељски чин европске културе ако би сагледање било онај принцип на основу којег је могуће говорити о неком јединству које се именује ријечју Европа), али се ни једног момента не смије превиђати да реакција не би била могућа без тих (и таквих) отварања и да је, као таква, у ствари саставни дио општијег „погона епохе”. Уистину филозофија се обилато служи „достигнућима” свога доба, али са битном напоменом: из свега тога она извлачи потпуно другачије поуке (него нпр. софистика). Масним словима ово треба подцртавати како би се избјегла пријетећа наивност сваког покушаја да се владајући дух времена ухвати „оком филозофије”, дакле оним што из тог духа устаје и наспрам њега се профилише. Стога, суштаствену карактеристику овог доба (која итекако бразда тијело филозофије) треба посебно издвојити, па тек онда ући у смисао филозофског разрачуна са владајућим духом времена.

Оно што снажно боји V вијек, у смислу да баш у њему сазријева (а видно је много раније), нека је врста нарастајуће свијести о прогресу и напредовању људског свијета. Наравно, Грци немају термин који би се слагао са нашим појмом напретка (нити је код њих као што ће се видјети о томе уопште ријеч).

12 Пар physis - nomos на епистемолошкој равни поклапа се са паром aletheia - doxa. Она „незаборавна“" (a-letheia) са софистима допада заборава, а на њено мјесто инсталира се nomos у смислу људског мишљење, сматрања, привида.

13 W. K. C. Guthrie; Повјест грчке филозофије III, Загреб, 2006, стр. 56. 
Једина грчка ријеч која би допуштала овај модерни превод била би auxesis. Она више дескриптивно означава нешто као „раст“, „увећање“ па и „напредак нечега у неком погледу“ - али не нужно и на боље. Можда то најснажније бива изражено пјевањем хора у Антигони - које не случајно бива честом филозофском темом, јер даје најобухватније и најсадржајније свједочанство, али и објашњење различитих људских умјешности које су обухваћене изразом „силина“ - „много силних ствари има, али ништа силније од човјека није“. Човјек посједује technai које превазилазе сва очекивања. Отуд, није безглава тврдња да је свијест о људској умјешности у основи епохе - самим тим и у основи искуства auxesis-a. Повећања знања, техничке умјешности у смислу грчке ријечи techne, видно је у свим областима - од умјетности и политике до ратовања и бродоградње. Отварају се нове могућности људског дјелања, а упоредо расте и свијест о тим могућностима. Конфронтација са традицијом (и то на свим „фронтовима живота“) је неминовна. Стари оријентири заказују јер тешко да су примјењиви на нову ситуацију. А да се човјек V вијека заиста обрео у једном новом подручју, види се по томе што по први пут одлуке мора доносити ослоњен искључиво на властите снаге (изгледа да су се бурне промјене десиле свега у неколико деценија). Тиме се и цјелокупна гравитација опажања мијења (што се једнако тиче и филозофије и софистике). Свакако да искуство „сопствене снаге“ разбуђује фасцинацију новим перспективама које су се отварале пред човјековим очима, али никако на начин модерне фасцинираности сопственим снагама. Ако је у Грчкој ријеч о свијести о могућностима треба знати да је она настајала, како каже Мајер, „упоредо са остваривањем тих могућности“, тако да није постојала свијест о цјелини процеса који је у току. Свијест о умјешности нешто је што је искључиво концентрисано у појединим „стручњацима и техничарима“, никако у грађанској јавности. Дакле ријеч је увијек о свијести о сопственој умјешности, а не о напретку по себи. ${ }^{14}$ Другачије: у V вијеку имамо

14 Отуд би се могло рећи да се и у Грчкој напредак подразумијева, јер је напредак нешто инхерентно животу, под условом да се прави разлика између „идеје“ (,обрасца“) напретка и напретка који одувијек постоји у животу појединца. Идеја напретка је образац који се протеже (боље рећи натеже) на све, она је највише уопштавање као пројекција на цјелокупну историју (у овом смислу, али и облику, идеја напретка није била одувијек могућа). Овакво протезање или облачење свега у „образац“ зове се још и историзаиија, а могуће је тек онда када је задобијено јединство „методички регулисане теорије склопа“ (Х. Блуменберг; Легитимност новог века; Нови Сад, 2004, стр. 31). Историзащија подразумијева овремењавања и темпорализацију свих затечених појмова, али свега тога код Грка напросто нема. Временска димензија античких појмова тешко да је постојала. Очекивање неких будућих побољшања још увијек није присутно. Зато је и промјена у грчком свијету ограниченог обима и увијек везана за одређене области. Модерна промјена је тако велика да нам се свијет указује као историја, напредак као нешто објективно, кретање бесконачног мноштва постаје знак времена, а друштвена структура постаје временска структура. У антици људи трагају за поретком који би одговарао оном што они стварно јесу, ми стремимо ка ономе што хоћемо да постанемо - нови људи. Античка очекивања су мала, наша огромна. Због тога су наша разочарања неупоредиво већа и стално траже компензацију. Кад се говори о модерном свијету J. Нестрој запажа да прогрес у њему изгледа већи него што у ствари јесте. Нисмо ли можда, кад размишљамо о старом свијету, суочени са супротним феноменом: да је стварни напредак био већи него што је изгледао? То не значи да Грци нису размишљали о 
посла са прогресивним овладавањем свијетом, а не са напретком који овладава свијетом.

Пошто свијест о повећања људских могућности код Грка увијек бива праћена снажним осјећањем (и свијешћу) коначности, дубоко је усађено мишљење да је достигнут врхунац у свему што се може постићи (што уосталом потврђују бројна свједочанства).

Дакле, свијест о умјешности увијек је и свијест о властитим претензијама и границама. То је једна ,јако колебљива свијест“. Тачно је да настаје услијед слома древног номистичког хоризонта, али та ломљава њоме још одјекује и производи разне гласове. Разногласност је стога њена суштинска ознака. Није она (како се воли приказивати) правоцртног усмјерења већ има многе полове испољавања. На једном полу изразито повјерење у људске снаге, изразит „оптимизам“, а на другом искључиви „скептицизам“ и најзад оно треће, што није ни једно ни друго, ни тамо ни овамо, нешто између - управо филозофија.

Из овог процјепа филозофија и формира своја стајалишта према владајућем настројењу времена. Тај положај у битном одређује њене визуре и њу као критику. Са данашњег становишта могло би се говорити и о битним ограничењима. Али и поред тога актуелност филозофске критике не јењава. Наравно, од В вијека до данас скоро све се измијенило. Али, све и скоро све јесу разлика. Ако се скоро све промијенило ипак је и много тога остало исто. Аналогије јесу опасне, али упркос томе, има се снажан „утисак“ да је сократска епоха колико год била далако итекако близу. Не без разлога се каже да је она “наше најближе иностранство" 15 .

Спољни описи прилика V вијека (било из примарних или секундарних извора) јасно указују да се ради о „највећој кризи грчког полиса“. Још антика овај кризни момент означава као процес „кварења полиса“ с којим упоредо маршира и „кварење говора“. Остајући без божанске заштите, без позадинске димензије светости, и ријеч, односно, говор бива препуштен себи, а тад он показује оно аветињско лице релативности. Увијек присутно клизање у значењима ријечи без обраћања спољном ауторитету, постаје застрашујуће. Играјућа димензија логоса истура се у први план. Идеал доба је єи் $\lambda \dot{\varepsilon} \gamma \varepsilon ı$ (добро рећи). Добро рећи није нужно истину рећи, већ успјешно говорити - пружити, пода-

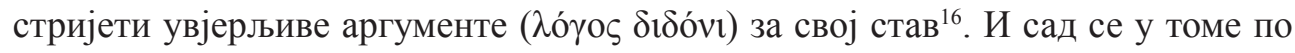

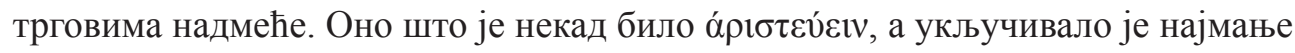

времену - већ само то да се, упркос многим изузетним запажањима и веома различитим закључцима о времену, упркос новим увидима, никад не опажа процес који тече у одређеном правцу. Вријеме носи промјене, али у једном суштински непромјењивом свијету (оп. видјети: К. Мајер; Настанак политичког код Грка, стр. 467-481).

15 U. Hölscher; Die Chance des Unbehagens, Göttingen, 1965, str. 81.

16 Филозоф је онај који остаје при пуном смислу ријечи таррұбí $\alpha$ која се обично преводи са слобода говора. Слобода говора могла је значити (и значи) између осталог и говорење лажи, иако изворно значи једино говорење истине - тачно у смислу Демокритове изреке: „треба истину говорити, а не бити рјечит" (Демокрит, Д/К, фр. 44 б). 
двије области: $\mu \alpha ́ \chi \varepsilon \sigma \theta \alpha \imath$ - „надмашити у борби“ (што је опет са своје стране укључивало низ врлина) и ґоvли́ - „надмашити у вијећу“, сада се сасвим сужава (тиме и снижава) и своди само на једну страну - надмашивање у вијећу ${ }^{17}$. Но, и ту је једна битна разлика: нововрсно надмашивање у вијећу не тражи више доказивање својих способности и добронамјерности (не надмаша се разборитошћу увида или знањем из искуства) већ само вјешто баратање ријечима. Платон је ту јасан: сад се надмаша глагољивошћу. Није више то агон аристократије него, „шепурење, помпезност, и еристика“ демократије. Глагољивост је залог успјеха и средство пробоја у политичком животу. Оспособити се за политички живот је научити овладати глагољивошћу (добро казивати). А „оспособљеност за политички живот“ код Грка одувијек је сматрана врлином. Према томе, глагољивост постаје врлина за коју се подучава. Видљиво је у којој мјери демократизација свих сегмената живота сасвим мијења нарав „оспособљености за политички живот“, самим тим и „нарав врлине“. Старе се вриједности у потпуности окрећу када се „оспособљеност за политички живот“ извуче из круга предиспонираности и мукотрпног процеса васпитања и увуче у круг technai (умијећа) којом могу сви овладати.

Мјерила времена (оног „сада“) постављају се за општа мјерила. Са филозофских осматрачница погубније ствари за човјека и заједницу нема. Стога се она развија и гради као евазивна страст - пробој оног „сада“ (она је суштаствено несавремена). Задаћа јој је не допустити савремености садашњег да се ,згруша“, да себи прибави изглед сигурности (чврстине и непромјењивости) - јер управо тим привидом она вјешто влада свиме што се појављује на њеном хоризонту. Као ,једино сигурна“ савременост садашњег обрушава се на све што јој се чини несигурним - а то је све друго и другачије од ње саме. Па може ли то друго уопште издржати ову навалу? У једном времену то се најприје односи на општости? Како „опште“ да опстане пред оним што се за њега и не обучава, пред оним што сматра да ту никаква обука и не треба? Како да „опште“ значи у једном свеопштем поравнању? Задаћа је надолазеће филозофије показати да човјек не одбацује стеге општег из неких слободарских накана и увида већ услијед слијепила и робовања најгоре врсте. Иако је истина увијек заједничка (иако је логос општи) свјетина ће увијек живјети као да има неку сопствену памет" (Хераклит, фр. 2). Одавно се показало да људима највише проблема задаје истина са којом стално и најпостојаније саобраћају - оно најближе људима је највише страно. А од страног се окреће. Тако се и од истине већина окреће и бира други пут - пут мимо истине, односно, мимо њезине тежине. А они који хоће тим људима (demosu) да се улагују све ће мјерити њиховим мјерилима и самјеравати њиховом укусу. Оно „високо“ мораће да се „снизи“, „велико“ мораће да се „умањи” - да би било по „средини“" и доступно свима. Али, бити по средини и у осредњости то значи промијенити своју средину. Тад све велико престаје да постоји. Бива мртво. А као што се види убијамо га „сви ми”.

17 Видјети: Ф. Зоре; Почетак и смисао метафизичких питања, Загреб, 2006. стр. 55. 
Платону је омражена ова „демократска средина” која духовност гуши сводећи је на културни догађај намијењен забави и занимљивости. Свака демократија црпи из демагогије и изворно је повезана са власничком потражњом, рећи ће Барт. У таквим околностима, настаје сушто изопачење чија је владавина и данас - док обућарство, фризерство итд. може бити и јесте “ствар изабраних" (оних који имају знање) политичка мудрост и умијеће постаје “ствар свих" - нешто за шта не треба никаква изабраност ни претходно знање (што је уосталом и главни приговор демократији од стране филозофа). Ствара се

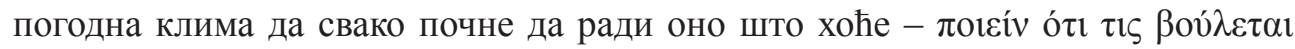
(Држава, 557б). Кад Бога нема, а ми то добро знамо, све је дозвољено.

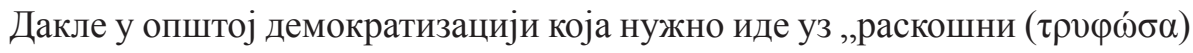

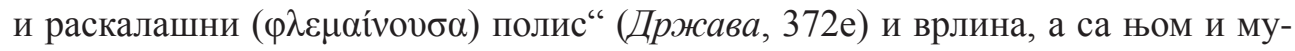
дрост, излазе на трг - нису више ствар одабраних тј. припремљених, већ су сваком доступне и треба их само покупити. Наравно, треба их и знати покупити. Стога софисти ${ }^{18}$. Они научавају врлину и за разлику од пријашњих времена обраћају се свим грађанима без изузетка. Ово „сви“ наравно односи се на „све који су спремни да плате“ за властито оспособљавање. Узимање плате за поуку јесте проблем за филозофе, али, чини се, никад у оном степену у којем је то била свеприсутна спремност да се за поуку плати. У њој (тој спремности) је сажет владајући духовни став епохе: „све се може купити (па и врлина)“. Овај став добија и своју стварну проходност па није чудо да човјек једино ту види пут пробој кроз шипражје свакодневног живота. Стога је у ширем кругу грађанства било загрантовано лако клизање софистике. Наравно да отпори постоје, они су јаки, те би наивно било сматрати да су Платон и Сократ искључиви кривци за негативну слику софиста ${ }^{19}$.

18 Као поборници common sense-а и широког образовања, те као учитељи техника који су требали помоћи у свакидашњем животу софисти су “изашли у сусрет потреби” (Т. Buchheim, Die Sophistik als Avangrade normalen Leben, Hamburg, 1986, str. 34). Неки од њих у платоновским дијалозима држе се једног доста статичног схватања о филозофији - из упућености у знање они одређују своје компентенције за комерцијални пренос знања. За разлику од њих Сократ заступа једно динамично поимање - код људи он не полази од посједовања већ од мањка знања. Филозофија је код њега заштитни знак људи као духовних бића са недостатцима. Платон начелно не одбија софисте (према некима као што Протагора гаји изизетне симпатије и поштовања) - осим радикланих случајева, већ посеже за темама техникама овладавања животом, за одговорима и хитним питањима времена које су софисти већ задали. Но он ставља другачије нагласке и преко контраста ствара нешто ново (M. Erler; Platon, München, 2006, стр. 63).

19 Sophos увијке алудира на неког зналца, умјешника тако да има јако широку употребу - од зналаца заната, вјештог човјека, доброг и племенитог човјека итд. Код Пиндара софист је искључиво пјесник. Вриједан термин попут овог, који изражава позитивно одобравање, нужно подлијеже подјели на истинит и лажан што ће умногоме утицати да ова ријеч почиње да губи на достојанству. Већ од раног V вијека ова ријеч почиње попримати негативне предзнаке и омаловажавајућу интонацију. „У рукама Аристофана то је без сумње постала ријеч која имплицира шарлатанство и превару...... Атињани су били склони сумњати у инелектуалце, мудраце и сличне. Њихови квалитети сажети су ријечи деинотес, од деинос - cmpax. Има у том знању „нечег страшног што се може обити о главу“ оном ко га посједује, а с друге стране, онај ко га посједује постаје објект сумње оним мање мудрим саграђанима. Да памет не мора бити употребљена у праве сврхе веома 
У сваком смислу, полис је постао мјесто гдје се радо и пуно говори ( полис је натекао, набрекао. Истине има мало, готово да је и нема јер све може бити истина. Истина је у кризи а та криза у основи је кризе полиса. Када више нема божанског као гаранта апсолутног важења истине смјеста се она самјерава „људским стањем“ - тј. постаје ствар људског става, боље речено, начина на који се став заступа. Самим тим, постаје нешто релативно, јер о свакој ствари може се говорити најмање на два различита начина, или изнијети барем двије различите поставке, двије истине. То је тзв. софистички dia-logos у смислу двојног логоса. Опстаје онај логос који је јачи, односно, увјерљивији. Отуд потреба да се најприје провјери шта неко држи за истину, па се насупрот тога поставља нова теза која се опет може утемељивати поступком давања разлога

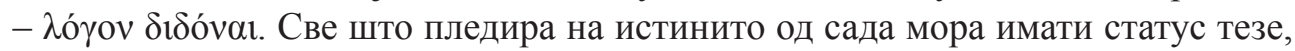
става. Онај ко у говору највичније заступа ставове тај је носилац истине, па барем један дан, јер већ сутра може заступати сасвим супротан став показујући да је он истинит. Тиме се само потврђује парменидовски усуд пута смртника: све се креће по супротностима и увијек натраг обрће, што јесте софистички увид у релативност и субјективност мнијења и установа.

Али овај увид не открива прави смисао кризе истине јер је и не разматра у погледу ње саме, него једино у односу на нешто друго. Тако је и са праведношћу и са добром - напросто, све се сада мјери једним мјерилом и на њега своди - мјерилом користи (то је само негативни момент људског номоса).

Када на том фону дјелује стари образац васпитања он се нужно извитоперује. Пјесничке се творевине окрећу у своју супротност - иста она поезија која је до некад уздизала „вишег човјека“ пред омладином претвара се у свједочанство овог изокренутог духа (све оно „велико и свето“дјеци се препоручује ради користи и плате). Настаје нека врста „савремене обичајности и обичајног васпитања“ (које је правом метом филозофске критике). Ова paideia, „изграђена на пјесничким облицима старије обичајности она напросто не посједује никакву отпорност против провале самовољног обртања посредством софистичког духа. Отуд сократско одбијање интерпретације пјесника и стална сумња да ли се мудрост старијих пјесника још увијек разумије..." ${ }^{20}$.

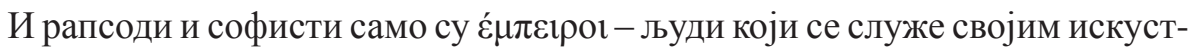
вом примјењући одређени број рецепата. Користити ријечи „божанских људи“, која је у једном свијету одређеном повезујућим дјеловањем и заједништвом међу људима могла бити најснажнији израз коју су очеви дајући узор додијелили дјеци, у новонасталим околностима (и за циљеве који из њих произилазе) може бити само светогрђе. И не само то: ријеч која би у овом залазећем времену и времену божанског окрета спријечила пропадање државног духа не може више уопште бити ријеч поезије (јер у „доба окрета““ и поезија постаје дио

рано се открива и искушава (о општем и специјалном значењу ријечи софист видјети: W. К. С. Guthrie; Повијест грчке филозоифије III, стр. 33).

20 Х. Г. Гадамер; Платон и песници, у: Филозофија и поезија, Београд, 2002, стр. 20. 
културног погона који преузима и према новим потребама тумачи сво старо пјесништво), већ нешто сасвим друго и другачије - управо дијалектичка форма усмености. Она је оформљена тако да уђе у спор са оним што је постало државни ethos, тj. са оним говорима који што све чега се дохвате окреће у његову супротност $^{21}$. А може тако да се оформи само зато јер „одлазак богова“ узима као разлог свог постојана.

Са боговима, све су прилике, одлазе и ограничења која су људски егоизам држали на узици. Људи попут Протагаре не маре за узмак богова - њихова савјест себе сматра довољно зрелом да издржи без било какве помоћи. И за већину софиста, али и данашњих учених, ослобођење појединца значило је неограничену слободу истицања самог себе, право без дужности, осим ако ово истицање није дужност. Оно што су њихови очеви звали самосавладавањем они су сматрали изговором за кукавичлук - вели Тукидид. Међутим та слобо-

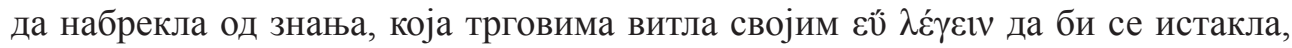
у ствари је онај „мјехур од сапунице“ у које се људско огрће, а кога Сократова дијалектичка усменост кани издувати. Он први одговара на софистичко незнање-свезнање, као и изокретање сваког знања у ситуацији када мноштво приграби мудрост као робу за продају. Не значи то да је Сократ једина реакција на софисте, али је засигурно прва која се „не даје у наивну потрагу за кривцима“. Сократ (код Платона) јасно види да у софистима не може лежати основни разлог за недаће доба. Они су само производ „полисног опадања“ отуд и веома значајни као појаснитељи основних идеја свог времена. Сократ често истиче да су софисти једини „на висини збивања“ времена. Окретати од њих главу“ зна-

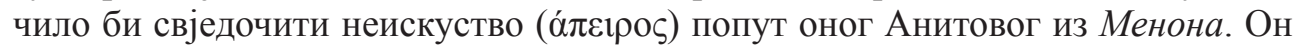
наиме не види да је „мудрост и врлина којом људи ваљано обитавају у кућама и државама“" (Менон, 91а) већ измилила из полиса и да није више лијеп ни добар сваки, било који Атињанин (Менон, 92а). Напросто, прошло су времена када се врлина могла преносити лако и несметано, сама од себе, са оца на сина, и наступило је оно доба у коме је њу „нужно научавати“. Полиса нема без васпитања, а васпитању увијек треба нека норма. Али када све старе норме (која почивају на номистичком мишљењу) почињу да губе садржај онда се и васпитање веже за оно једино остајуће, а то је форма човјека. Васпитање постаје формално. И непроцјењив је значај софистике у томе што се први повлаче „на уску основу људског живота“ (Јегер). Но управо је њихов „начин повлачења“ филозофији споран - јер остаје слијеп за оно на шта се повлачи. Сократ софисте мора „узети у обзир“ и суочити се с њима „на њиховом терену“. Руку на срце - неког другог у том тренутку и нема.

21 Отуд филозофдска критика пјесника од почетка полази од тога да пјесма мисли, да садржи одређен облик знања и да може послужити у педагошке сврхе. Платон критикује рапсоде, а рапсоди, за разлику од аеда, јесу као што и сама ријеч каже они који „шију“ пјесме, што значи да улога рапсода, како Сократ инсистира у Ијону, није само да посредује у упознавању са поезијом коју евентулно баш он открива публици већ и да оспосби публику да је разумије. Он је и онај који бира стихове према њиховом предмету и утиску који треба да оставе на публику, али онај који суди о прикладности текста - његова је функција заправо функција критичатра (видјети: Ж. Ф. Прадо; Увод у читаъе Ијона, у: Платон; Ијон, Београд, 2010, стр.15). 
Ако је вјечни поредак ишчезао остаје једино вријеме у својој ширини и бескрајности промјењивога. Сада је главно питање: како у времену наћи поредак, како наћи неки ред у сталном гибању и мијени? На човјеку је да ријеши овај „проблем“. Њега рјешавајући он себе разрјешава за властиту суштину. Одлучује се. Дакле, не само да човјек јесте онај који рјешава проблем него се проблем рјешава у самом човјеку. Односно, човјек, оно човјечно у њему, ако се до њега дође, јесте рјешење. И нема човјека, није га било и неће га бити, којег би сократска дилема мимоишла, без обзира на степен свијести о њој и интензитет њеног искушења. Није то било какав дилема него „страшна и тешка“ дилема људске слободе. Левинасовски речено, то је тежина која је већ пала на нас и коју никакво схватање или разумијевање, никакво знање, не може олакшати. Свако олакшавање, избјегавање, овдје је одустајање од себе. А од себе се одустаје јер се не обучава у „чудесном стражарењу“ које пада на човјека, у „бесмртној борби“ са непријатељем најгоре врсте. Али шта значи обучити се у „чудесном стражарењу“?

За Сократа само једно - вјежбати се за филозофију, јер само она је кадра детектовати највећу опасност за човјека, тј. показати да непријатељ није с ону страну зидина полиса, није неко други, нити долази од некуд другдје, већ је ту у срцу полиса, тачније у срцу људске природе. А како јој то „полази за руком“?

Па једино тако што оно људско искушава „до краја“, што се баца у оно

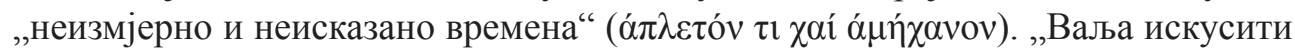

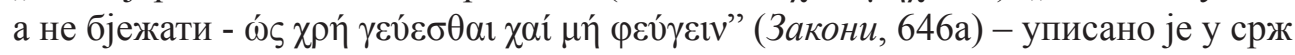
филозофске дјелатности (а као натпис требало би стајати на сваком мјесту гдје се данас филозофија изучава и предаје).

И тек сад омогућен је увид у пуни филозофски смисао „кризе истине“. Њега артикулише помињани Гајзеров став с почетка: „повлачење и суспрезање истине, тј. „окрет божанског“ у ствари отвара животни простор филозофије. Она је могућа јер су богови отишли, тачније: они су отишли и њу пустили да дође. Говорећи у модерном регистру: суспрезање истине омогућује слободно мишљење, односно, суспрезање истовремено „испружа човјеково Ја у његовој мислећој дјелатности, као једини медиј у коме се истини још може отварати и тако је чувати од заборава“"22.

Не би шкодило мало застати како се не би затамњивало тамо гдје су ствари најјасније дате. „Суспрезање истине“ порађа свијест (рефлексију) - то је разумљиво, јер суспрезање омогућује да се човјек одвоји и ослободи непосредног односа са бићем. Чин одвајање јесте рефлексија. Она сада постаје принципом истраживања истине (јер остала је само човјекова свијест - и строго говорећи, каже Ципра, „прије софиста и Сократа нема свијести у филозофском смислу“). Но да би се ова принципијелност уистину схватила треба знати да нема неке готове свијести (logosa) која долази изнебуха и одмах сијече и одваја, већ се она догађа на леђима процеса повлачења истине (mythosa). Дакле, ако се порађање

22 Оп. видјети. М. Ципра; Метаморфозе метафизике, Загреб, 1999, стр. 118-119. 
свијести мисли у смислу разрјешења саме истине (одлуке као крисис, одлучења саме истине) јасно је да тај догађај отвара цјелокупну духовну стварност човјека. Он „приноси свијест“, али поред свијести човјеку дарује (отвара) и душу као његово истинско, потпуно биће. У душу се сад истина смјешта како би била поново откривена (истина се уписује у човјека и на тај начин богови никад и не напуштају човјека). Свијест је „само појава истинског бића човјека, појава и привид душе, као човјекове истинске збиље. Свијест је онда nomos, а душа je physis“'23. И тек уколико се свијест обрати бићу своје душе имамо мишљење. „Упознај себе самог“ позив је свјесном Ја да се врати на своје поријекло - на пред-свјесну и над свјесну душевну збиљу. Јер док год Ја инсистира на свом апсолутном егоитету, као принципу свега, душа је раздвојена (располућена) и обитава у привиду свијести. Филозофија онда није друго до мегдан унутра себе којим се покушава снизити ово Ја, или речено у хришћанском вокабулару, она је пустошење егоизма, себе-пролажење. Само тако душа задобија прилику да разријеши привид свијести и да свијест преобрази у истинско људско биће. Другим ријечима, разум треба привести уму. Ово привођење није хтјело бити хапшење већ привола (софист никад није требао бити потрвен већ само модификован) која се одвија путем „,темељне расправе с привидом“. Овај пут у Федону се описује не само као најбољи него за смртника и једини могући пут. Расправа с привидом није друго него његова проблематизација (из чега произилази тематизација разума, људског номоса), темељан пролазак кроз њега како би човјек постао свјестан узрока и начина искривљења властитог мишљења. Свијест о искривљењу већ подиже мишљење, оно се исправља и на тај начин гради оно спомињање на заборављено, на заборав заборављенога (кога очитује софистички номос) $)^{24}$.

Управо тематизацијом људског nomosa (разума) нараста потреба да се његова негативна страна допуни позитивном. Када Сократ понавља древни став: људски је закон само изданак оног божанског и вјечног закона., то није тек пуко слијеђење традиције већ освједочење дубоког филозофског увида: закони који одувијек живе и за које нико не зна одакле потичу не могу престати да важе декретом разума, тј. човјековом самовољом, јер постоји првотнија „воља“ коју разум мора поштовати да би уопште био разборит и достојан човјека. Но за поштовање (као и за човјека) треба се обучити. Обука јесте у мишљењу. И јесте мишљење темеља̄. Стога Сократ поново призива законе од бога дате thésmoi ${ }^{25}$, mе отвара простор гдје се уистину може чути юихов непролазни

23 Ибид, стр. 120.

24 У једном строгом смислу не постоји мишљење а да није погођено истином јер оно што се повлачи на посебан начин даје се мишљењу - не да би мишљење њиме располагало него да би му се се ставило на располагање и тиме себе испунило суштином. Па онда, „истини за вољу“ погрешног мишљења и нема, постоје само „искривљена мишљења“. Но, мишљење се не може искривити само од себе. Њега криви једино излагање, односно медиј у ком се излаже - а то је говор.

25 Thémis се обично јавља код Хомера као „басилеусов атрибут који је небеског порекла, а множина thémistes означава скуп прописа, божански надахнут зборник неписаних закона, збирку изрека, забрана... којима се утврђује примерен начин поступања у свим приликама када се ради 
зов - сопство. Ко поново чује почетно дозивање тај се буди. Пробућени тражи правду, јер Заборављено тражи правду - зато и буди. „Правда је традииија заборављеног“ - каже Агамбен. Примарно, „правда се не рађа као дискурс кога ваља прешутјети или учинити приступачним, већ као глас, не као аутографски тестамент него геста најаве или каква вокаџија“26.

Речено с Платоном: окретање свијета у суноврат, и с юим повезано самосуспрезање истине, разбуђују филозофа. Тек кад Ред ишчезне из људског свијета филозоф се почиње бавити „уређењем“ људских ствари, полиса и душе, и једино тим бављењем (бригом) поново изналази, увиђа Ред, а тај га увид надахюује и окреће ка искону. Богови који су отишли опет су ту, овај пут у мишьеюу. У надахнућу и кроз надахнуће мишьеюь увијек вије божански дах. У заносу, надахнућу, човјек се окреће и опонаша епоху присутних богова.

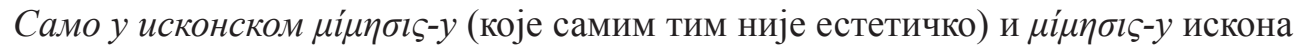
станује спасење ${ }^{27}$.

У том смислу, старим се увијек ваља опомињати и њему се враћати јер оно не умије да пролази (суштински се од њега не може ни отићи а да то истовремено не буде и привид одласка). Али, постоји потпуна свијест о немогућности једноставног враћања. Подједнако као релативизам и скептицизам софиста „лутање“ полиса изазива и привид да се старом може вратити без рефлексије, тј. да је довољно, „као пијан плота“ држати се традиције. Овим привидним знањем полис себе осљепљује онако како је некад у доба своје првобитне среће осљепљен Едип (Паточка).

Из тог процјепа и из тог зијева, на једној пустопољини и ничијој земљи, у једном између и као то између (које треба остати) рађаће се филозофија. А филозоф „напет“ између наоко неспојивог ту је да свједочи могућност континуума, да поново сагради покидане мостове и везе јединствене стварности и „идући правди у помоћ“ на најбољи начин гради, чува и упражњава друш-

о поретку унутар génos-a“... То друштвено устројство још боље се да сагледати, каже Бневенист, из обрнуте визуре када пјесник говори о земљи Киклопа као о оном athémistes - „код њих нема ни зборова на којима се доносе заједничке одлуке, ни thémistes; свако упражњава властити закон (themisteúei ) над својом женом и децом, и нико не хаје за друге. То је сјајна илустрација правог значења ријечи thémis. Тамо где нема génos-a нити краља, не постоје ни thémis ни скупштина; свака породица живи по свом сопственом закону. Ти Киклопи су прави дивљаци“ (Е. Бенвенист, Речник индоевропских установа, стр. 320).

26 „У том смислу, није Logos него Dike најстарија људска традиција (изворно су оне неразлучиве) Вјерујући да си преносе језик, људи заправо размјењују гласове и, говорећи, без опроста препуштају се правди“ (Ђ. Агамбен; Идеја прозе, Загреб, 2004, стр. 63-64).

27 Увијек је јасна свијест (и то је најдубља платоновска отријежњеност) да све што човјек оствари ипак се може звати отјелотворењем Добра, веч је mimema, не-једнакост, различитост, неко не-Добро. Али само тако, дакле поричући се, Добро би могло да се појави. Али ни за то појављивање-порицање никада нису довољне људске врлине: потребан ће бити и срећан случај, божанска инспирација. Отуд ни Држава није говор о правој држави која није, него о идеји која једино може измерити постојећа устројства. Говор који је бескориснији од свих и нужнији од свих. Он буди, отрјежњује, просвјетљава aechanon kallos Добра, пошто показује да, на неки начин, није само Добро то што у свему томе учествује“ (М. Качари; нав. дјело, стр. 34). 
твеност. Уједно, то је дубока свијест о из-зглобљености како из цјелине митског поретка тако и из разумског поретка уобичајеног. Имати снаге да се све то свједочи јесте дати значај самом из-зглобљењу, пробудити се за властито бескућништво у које се позван. Наравно то није поставити из-зглобљеност као мјеродавност, већ супротно самоупутити се ка новом и другачијем у-збиљењу, у-озбиљењу, поновном утемељењу у цјелини свега што јесте.

Платон је први послушатељ који истину древности умије довести у везу са Сократовим неуморним и доживотним трагањем за мјером, без које не би било образовања, нити би нешто као култура могло да постоји, како то тврди

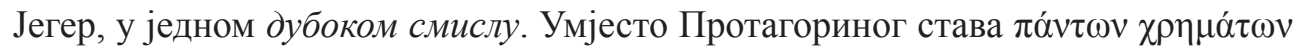

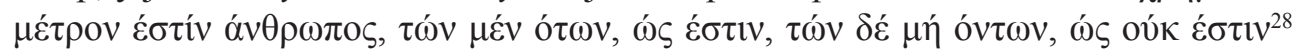
- који изглобљење узима као мјерило ${ }^{29}$, Платон у из-зглобљеноси види изван-

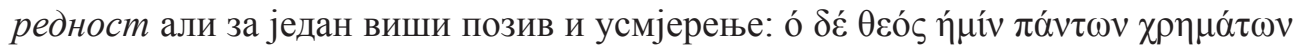

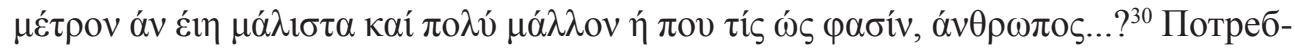
но је да антропоцентризам софиста буде замијењен реактуелизованим (мисаоним) теоцентризмом - бог је мјера, а истинска паидеиа утемељена је на богу као највишој норми. Теоцентризам филозофије не значи поврат митотворству, већ је резултат и најдубљи израз искуствовања људске егзистенције - јер ни у ком случају и ни под каквим околностима не може човјек бити давалац властитог мјеста (taxis) у постојању, већ је то увијек нешто друго, бескрајно другачије.

У том смислу филозофија је само врхунац оне специфично грчке свијести о људској умјешности која је увијек на опрезу када је ријеч о „провали“ оне силе што човјека узохољује, а коју Грци називају fren - разум. Од давнина се говори о провали разума. И добро се говори, јер не познаје се нешто као природни раст разума - постоји само провала, навала. Разум је незасит када треба запосјести подручје које настаје повлачењем истине. Његово својатање тог терена грчки дух одмах означава као нешто опасно и за човјека погубно. Оштрица Демокритових ријечи може пробијати и платна савремености: „Убоги разуме, од нас узимаш своје аргументе и с њима хоћеш да нас срушиш. Твоја побједа биће твој пораз“ (Б 125, Д/К). Нешто слично, више у виду императива

28 “Човјек је мјерило свих ствари, оних које постоје да јесу, оних које не постоје да нису" - ово је сачувана изрека којом је, кажу, почињао Протагорин спис А $\lambda \dot{\theta} \theta \varepsilon 1 \alpha$. (видјети о томе: G. Vlastos; Protagoras, u: Sophistik, Wissenschaftliche Buchgesellschaft, Darmstadt, 1976).

29 Платон сматра да се Протагорина релативизација најприје односи на појам бића. У ствари ријеч је о крајњем заоштравању старе елејске тезе о саприпадности мишљења и бића, које је искривљује до непрепознатљивости. Иако полемика око стауса Приотагорине тезе и данас траје треба рећи да се већ у антици (а никако да је то резултат новијих истраживања) зачињу мишљења по којима ово учење о бићу није потпуно неспојиво са елејским. Оно битно јесте да софистичко релативизовање појма бића (имајући у виду антички појам мишљења) не може бити истозначно са његовим субјективирањем у смислу новјековне филозофије субјективности (што испада као посљедица неокантовских интерпретрација Платона). Видјети оп: Г. Гретић; Традиција метафизике, Загреб, 1989, стр. 32)

30 “Бог би нам, дакле, био највише мјерило свих ствари, и то знатно више него било који човјек, како сада говори.” (Платон, Закони, 716ц.) 


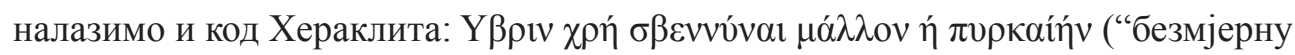
дрскост треба гасити прије него пожар“). Такође и Парменид мајсторски поучава да остајање код разума није у стању поштовати унутрашњу консеквенцу логичкога мишљења које увијек стоји придржано уз божанску димензију. И је ли онда основна тема мишљења раних филозофа пхусис у смислу физиологизма како то Аристотел хоће? ${ }^{31}$ Или је и код њих на дјелу тема која у разним формама не престаје опсједати грчки свијет: безбројне заблуде којима су људи по својој природи изложени? Понекад њихова промишљања заиста дјелују као крик над људима и њиховом неразумношћу. Тај крик је и Сократов, он се разлијеже трговима не би ли га и други чули као највластитији. Као такав долази и до нас. Његова снага јача упоредо са људском неспособношћу да га чује. Он носи истину о људском, о људској умјешности коју засљепљен собом човјек заборавља. Зато много више од пуке приче значи Платонов указ на то да људска

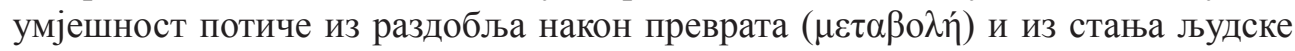

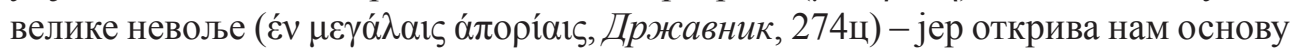
искуства божјег узмака. Кад нема богова распростире се људска умјешност али она није изналазак људи. Људи бијаху сасвим беспомоћни све док нису добили дарове $(\delta \omega ́ \rho \alpha)$ од богова - а највећи дар поред прометејске ватре, јесте онај од Атине и Хефеста - $\tau \dot{\varepsilon} \chi v \alpha 1$. Пошто су богови опремили и свијет и човјека за њихов самостални опстанак то ни њихови дарови не могу по себи бити разлогом кварења свијета. Те́ $\chi v \alpha \iota$ су израз божје бриге о човјеку и у свом исконском облику оне теже божанском. Али кад се свијет „напуни смртним и тјелесним, а људска ћуд превлада“" све се то прекрива заборавом. А филозофија није друго него напор (памћења) да се дигне застор, и “да се путем људске $\tau \dot{\chi} \chi v \alpha \iota$ поново успостави божански поредак”32. Да би се град лијечио од зала потребно је познавати његову прошлост, да би почео да слуша законе потребно је познавати истинско поријекло тога, одважити се на путовање у аделон, у не-видљиво, у оно чему је изгледало немогуће да се нађе хистор. Једном ријечју, човјеку је

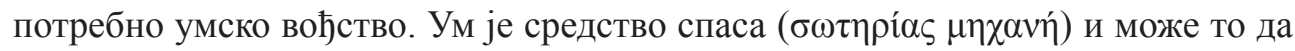
буде јер себе стално усмјерава на оно једно и јединствено.

Каликле подругљиво приговара Сократу да говори „увијек исто“ (ácí $\tau \alpha v ́ \tau \alpha ́)$. Сократ му не остаје дужан смјеста допуњавајући приговор: „не само то, него и о истим стварима“" (Горгија 490е-491б). Тиме Сократ и од Каликла тражи исто, мада зна да он за то напросто није кадар јер се ослања искључиво на природни разум који нигдје и ни у чему не умије наћи никакву константност (оно исто). А филозофија се увијек са истим мотивом враћа истом питању и

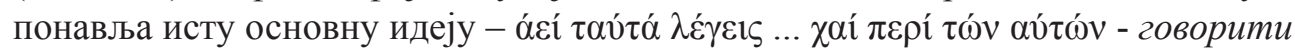
исто и о истом (Горгија 490е). Никада на „празно“ и не упркос времену него баш из времена. Отуд и има снаге указати на далекосежне посљедице које релативитетни назори на свијет имају у животу. Кроз њихово демонтирање она

31 Тим прије што по многим ауторима ријеч phusis у старом језику значи најприје суштину, а не природни свијет (у овом значењу ријеч се појављује тек од Горгије).

32 J. Kube; TEXNH und APETH. Sophistisches und platonisches Tugendwissen, Berlin, 1969, str. 223. 
указује на једностраност испод које вребају и тоталитарне амбиције: ако релативизам себе поставља као једино важећи, и ако је он тај који успоставља важења, тад он хоће да вриједи апсолутно. Зато софистички антропоцентризам (често и не без разлога помиње се „вулгарни антропцентризам“) у усредсређености на властито „савршенство“ забрањује сваку спекулацију о недокучивом и показује емфатичку нетрпељивост према могућностима рационалног приступа подручју не-видљивог - adelon. Управо у том подручју мишљење, ако је ваљано, проналази „оно исто“ помоћу којега једино и познаје и спознаје и оно промјењиво.

Човјек је ,уроњен у датост“, али датост нуди потпун садржај своје стварности тек ако се из ње искорачи, односно, ако се не узима за оно за шта се приказује (издаје) већ са ослонцем и темељом у оквиру цјелине. Тиме се ослобађа и она друга духован страна човјекова - пале се очи душе. Ко хоће, попут софисте, да само једном страном ословљава бивствујуће тај се већ заробио а и мишљењу рекао је збогом. И свако доба врви од оних „сигурних“ људи, којима је пут један и сасвим прегледан. Упозоравају нас да такве треба избјегавати. Ако смо поуку примили онда би избјегавање требало почети најприје од себе јер одавно постасмо они на које су нас упозоравали (Слотердајк).

Дакле, без нечег константног, јединцатог, нема ни ваљаног људског живота. Не случајно Платон стално понавља да губитак општеобавезности указује да су и појединац и заједница пали на раван животињскога. Јер никад није било ријечи, нити ће бити, о томе да општеобавезнога нема или уистину нема, већ о томе да оно престаје бити за нас. Истина је прикривена, о боговима не знамо много, мањка свеколика мудрост, али да ли то значи да истине и богова, па и мудрости код богова, нема, и да нам је искуство тога унапријед затворено и запријечено? Или, како би то у савремености прослиједио Левинас: да ли смо уистину сигурни да Бог ћути?

Нису ово питања која се напросто поставе већ питања у којима учимо себе цијели живот постављати. А у њих доводи само храброст којом логос „својом вољом себе самог убацује у посвемашњу рђавост“ (Закони, 646б) и без игноранције улази у „пуко, неукрашено људско“. Филозофија може рачунати с тим да буде неки наук само ако се руководи не илузијама већ оним шта и како јесте.

А јесте тако, некад као и сад, да су „највише по природи људско насладе, болови и пожуде. Нужно је свако биће уз њих уско везано па их се чврсто држи највећом ревношћу“. Оне напросто „прате сваки наш чин“, али треба ли их ,залијевати и постављати их као наше господаре“ (Држава, 606д) - кључно је сократско питање упућено пјесницима и софистима, али једнако и нама самима.

Насладе, ситна задовољства, ако се око њих организује сва брига живота постају човјеков највећи непријатељ. Али зашто је, по мишљењу филозофа, наслада највећи непријатељ човјека? 
Најприје јер „у насладама“ живот себе уобручује, своди само на једну своју раван. Тежина стајања у слободи, об-стајања, јесте оно што одвраћа човјека и баца га у наручје наслада. Радо се “трчи у игру и у необавезност”, па се и двоструко склања од свега тешког и озбиљног у живот уписаног. Али шта је то у коријену насладе па развија такву грамзивост за лакоћом постојања којој ниједно вријеме не измиче?

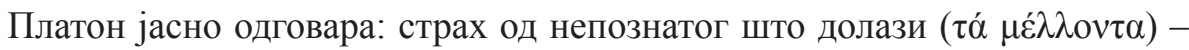
од смрти. У необавезно се бјежи јер обавезно у себи носи и нешто "страшнога". Човјек се препушта времену и његовим стихијама да не би много мислио и себи живот отежавао. Не мислећи човјек у ствари шутке изговара једину мисао која постаје догма сваке лаке мудрости - увијек бити.

Бити увијек - прва је и најдубља пожуда коначнога бића изникла из неотклоњивог јада и чемера људског живота. Она се подгријава неспремношћу да се на прави начин искуси, а онда и издржи, истина да је човјек “неизљечи-

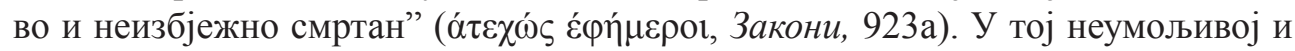
неотклоњивој истини живот говори о ономе о чему га насладе приморавају да шути. Насладе не гледају животу у очи, у њима се живот не преиспитује. Као што је карактеристика природног гледања превиђање тако је и карактеристика насладе заобилажење и олакшавање ${ }^{33}$.

Права опасност је у томе што на насладу усмјерен живот показује снажан порив за осамостаљењем. На ову опасност филозофија се и обрушава, дакле, не насладу као такву већ на насладу као руководство живота ${ }^{34}$. Онај који је према насладама крут у суштини се не разликује од оног ко им стално попушта јер једнако свједочи неискуство у насладама. Стећи овдје искуство јесте видјети да између крајње крутости и крајње попустљивости стоји „гипка чврстоћа“ као мјера правог живота. А до овог увида може доћи само онај који интензивно живи. Он искушава опасност осамостаљења живота у насладама и из тог искуства говори. Отуд знање да осамостаљење наслада није друго до осамостаљење привида. Да је тако свједоче свакодневна схваћања којих се држи већина људи. Све је код њих концентрисано на бригу око насладе и избјегавање боли (Федон, 65a). Насладе је „добро живота“, и не само то, у њој се види „животност живота и душе“. То значи да оно што је живот сасвим везује за тијело и све оно што му припада (од најразличитијих баналности до врло важних брига и догађаја). Што је тијелу угодно добро је, а све што такво није јесте зло и треба га се клонити. За Сократа оваква је организација живота дубоко проблематична, јер њоме живот сам себи поставља клопке у које (због свог душевног усмјерења) не престаје упадати. Наиме, ако се окреће наслади човјек смјеста прихвата и бол, јер бол је нешто што је “једним својим крајем" спојено са насладом. Самим тим, живот који је тако схваћен стално бива осуђен на оно што хоће да

33 О свему опширније видјети засигурно један од најуспјелијих списа о Платону на овим просторима: Д. Барабарић; Политика Платонових Закона. Увод у студиј Платона, Загреб, 1986, стр. 61-82

34 О еротичном код Грка видјети: Н. Licht; Sittengeschichte Griechenlands, Stuttgart, 1965. 
избјегне. У тој самоосуди он једноставно прође, напросто прође. Ту је, а као да га нема - сломљен је у привид. Онда човјек траје, не живи. Има очи, а не гледа. Будан спава. Слијеп је. Душа му је слијепа. И ето је страшна рупа „посред бића“ која се ничим од овога свијета не може затрпати. Кад је рупа у „бити“ све се може “имати” а она ће и даље расти. Тад се види како „имање“ промашује „бивање“ - како је оријентација на „имање“ промашај битнога.

Сљепило душе извор је свих зала. Оно се огледа у томе што душа не умије препознати привид, нити „привидност привида“, односно не познаје “цјелину привида као таквог”. Кад је привид оно најјасније и најистинитије унутар њега као цјелине дају се само привидне алтернативе и супротности схваћања и чињења. Напросто, кад услијед сљепоће за цјелину са̂м привид постане „цјелина“, онда не може више бити ничег чврстог и стаменог. Све оно у суштини стамено ту се мора показати као привидно. У окружењу „привида као цјелине“ чини се да има људи који нпр. дјелују храбро, али они у таквој ситуацији то не чине зато што су храбри него што се боје веће неугоде од оне коју морају претрпјети дјелујући храбро. Храброст је утемељена на страху, а тада (и таква) и није храброст. Исто се збива и са другим врлинама - не мањка умјерених људи, али они су умјерени због неумјерености, односно, због страха да ће због једних (мањих) наслада изгубити друге (веће) насладе.

На тај начин успоставља се „општа економија“ свакодневице: размјењује се страх за страх, наслада за насладу и све у бескрај (при чему је тај бескрај у ствари отужни крај /предио/ оног „од данас до сутра“). Брига око насладе, и економија те бриге, збацује сваки постојани чврсти лик и закон, те инсталирају свој закон по којем је наслада сама себи сврхом. Сократ показује да се управо томе препуштају и пјесници - бахантујући, и софисти - обузети снагом разума. У опијености насладом они заборављају старе законе и мијешају све са свиме да би показали да је наслада једина суштина и тако народ увјерили на одважност да је сам довољан да суди. Отуд жеђ за новотаријама на сваком кораку. Умјесто старих култова развија се култ новотарија преко којих се чува и проноси мудрост дана - жеђ за новим ствара привид да је живот само она снажна енергија младости опијена сама собом док је смрт још далеко. До данас је то тако - бјежећи у тјелесне насладе живот у ствари жуди за бесмртношћу “која је по природи изникла баш сваком да је има” (Закони, 721б) - живјети увијек и не умријети никад, живјети као да смрти и нема. И ова жеља за бесмртношћу будући и јака и лака сваку другу ће прогласити за тричарију.

Спремно се у овим стварима можемо дати за свједоке: класична питања, мотиви и истине „као цјепидлачење на ријечима“ застарјела су и ометају нашу „вјечно младу“ свијест. Парадоксално, али показује се да застарјевати може једино младост свијести у којој за ове истине више нема мјеста. Шелинг је ову матрицу лијепо описао: душа ствара мисли, оне се осамостаљују као посебна сила и савладавају своју родитељку подвргавајући је себи (знању), а тад се човјек не окреће себи него поствареном дијелу себе. И зар данас неко може одбити налаз да је у трошењу трансценденције у иманенцији коначно ријеч 
била само о томе да се „комфорно опреми точак по којем трчи хрчак у кавезу“ (Р. Зафрански)

Нада вјечног трајања у потпуности заведена пожудом (насладама) губи прилику самоодмјеравања у искушењу оног заиста страшног и тешког (смрти, коначности) и тако се пуни обијешћу и самољубљем - „као да не треба никаквог господара ни вођу“ и зато остаје „пуста и од бога остављена“ те „скаче пореметивши и смијешавши све у једном“. Суштина обијести јесте изостанак мјере, одмјеравања и оног с чим се одмјерава које свему и свакоме даје његово право мјесто.

Но, свакодневица ипак одаје привид неког дјеловања, душевног кретања. Душа се заиста и креће, али само унутар привида, тј. душа себи купује (прибавља) привид мијењања. Том куповином себе засљепљује. Човјек увијек остаје у мочвари из које мисли (мније) да се уздигао. И ето како до дана данашњег настаје „паланачки дух“ и „малограђанштина“, како се гради „кристални дворац“ којег Достојевски зове „сви ми“. Дакле, кретање душе унутар економије свакодневице не може бити истинско кретање јер се увијек у истом креће (и по истом). А кад се тако креће не дешава се истинска промјена - „неће бити права замјена за крепост мијењати сласт за сласт, бол за бол, страх за страх, и веће за мање, као новце, већ ће само онај новац бити прави за који треба све то мијењати, наиме, спознаја“ (Федон, 69а). Не може се десити промјена без промјене увида - „истинско куповање“, а то је кретање и мијењање, јесте оно спознајом. Спознавајуће мијењање води промјени у друго, а не из истога у исто - јер оно је себе-размицање за искуство неумољиве другости божанског. Ово промјена, конкретан преображај бића, могућа је само на подлози оне храбрости која се спушта у бездан живота, јер само она „погађа“ бога. Погађајући бога погађа човјек и своју мјеру. А погодити бога није друго него „погодити“ неумољиву диференцију свијета који је божански. Свијет је диферентан и нема разлога, он је мистериј ${ }^{35}$ који се објављује остајући скривеним. Искуство дифе-

35 Мистериј није лажни сјај помоћу којег потајним смислом, силним уздасима и недокучивим алузијама треба обогатити свијет, већ само оно што је модерна свијест свијету одузела стављајући га на располагање разумским израчунима - његову божанскост. „Мистериј живи као такав увијек кад мисао управља према њему властито испитивање и једино ако, умјесто да занијеми пред оним несхватљивим, поднесе парадокс мишљења загонетке у њеној неодгонетљивости. У поштовању према њој мисао налази властиту pietas која је нешто друго од сна и празновјерја, јер се храни пропитивањем. Стога је она такође нешто друго у односу на ону израдбу разлога у облику израчуна и објашњања“... Само што увијек већ некако разумије мистериј филозофија га посјећује својим испитивањем. То је њена служба божја. Никад не тражећи дефинитиван одговор она је вођена потребом за Другим. Стога, filein није мушичавост духа него насушна потреба егзистенције да не изгуби однос с оним што је де-финира као коначну, и тако издржи у својој необразложивости. Често изгубљен човјек је „способан кренути сваким путем, он тумара према богу, никад дефинитиван али ипак увијек дефинитан, тј ограничен другошћу која га позива да буде оно што треба бити. И нема мистерија који не би био мишљен као што нема мисли која не испитује мистериј. То је парадокс филозофије - не као разрјешења него као откровења егзистенције. Мистериј човјечнога јесте Бог - онај други од ког је различит и од ког прима мјеру своје коначности - као што је мистериј бога човјек - оно мјесто гдје се он можа објавити““ (М. Руђенини; Одсутни бог, Загреб, 2005, стр. 126-127). 
ренције, искуство “другости” јесте искуство божанског (које се не да склонити захтјевима разума за смислом) али и радикално искуство коначности. Ко га задобије издржава битно незнање и без узмицања живи своју смртност. Он је с богом и зна да нема живота са богом који уједно не би био и „најистинитија трагедија“ и „најсјајнија драма“36. А то може знати само јер искушавајући живот „иде до краја““. Од живота не бјежи насладу гањајући, већ се се прибира око оног најбољег у себи - а то је юегова душа. Грчка мудрост „није утјешна, не умирује човјека нити га образлаже“, само му излаже његово суштаствено мјесто - оно између људскога и божанскога. Она му отвара очи за бројне заблуде којима је на свом путу изложен, а понајприје оне којима га излаже сопствени разум и његова умишљеност.

36 Видјети: Д. Барбарић; Политика Платонових Закона.., стр. 97. 